\title{
5. STRUCTURE AND DYNAMICS OF THE LAMBERT GLACIER-AMERY ICE SHELF SYSTEM: IMPLICATIONS FOR THE ORIGIN OF PRYDZ BAY SEDIMENTS ${ }^{1}$
}

\author{
Michael J. Hambrey ${ }^{2}$
}

\begin{abstract}
Depositional processes in Prydz Bay during the past $40 \mathrm{~m} . \mathrm{y}$. or so have been strongly influenced by glacier ice. Therefore, to understand these processes better, and to define the source areas of the sediment, it is necessary to determine the role of the different ice masses entering the bay. Ice thickness, topography, and ice velocity data indicate that the Lambert Glacier-Amery Ice Shelf system is one of the most important routes for the discharge of ice from the East Antarctic Ice Sheet, and in the past has been the dominant influence on sedimentation in Prydz Bay. Most of the flow is concentrated through the Lambert Graben, which has been overdeepened to a depth of $2500 \mathrm{~m}$ below sea level. Glaciological work has indicated that close to the grounding line there is considerable melting, but from a short distance seaward of this position, basal freeze-on of ice of oceanic origin occurs. Thus nearly all the basal debris load in the Lambert Glacier system may be deposited close to the grounding line, and that there is probably negligible deposition beneath the major part of the Amery Ice Shelf. Englacial debris, delivered to the open sea through the interior of the ice shelf, will be deposited from icebergs.

There have been conflicting reports concerning the dynamics of the Lambert Glacier-Amery Ice Shelf system. One hypothesis is that the system is not in steady state and thus may be prone to surging. The alternative hypothesis is that the glacier system is in steady state, with no evidence of surging. Consideration of the pattern of ice structures can help to resolve this question.

Mapping of structures in glaciers yields fundamental information about ice dynamics. For the Lambert GlacierAmery Ice Shelf system, Landsat images have permitted the mapping of ice foliation, moraines, and crevasses. As the geometry of these structures is incompatible with pulsating ice flow, it is argued that surging has not occurred during the residence time of ice in the Lambert Glacier-Amery Ice Shelf system, which is estimated as lasting up to several thousand years. The structures are also used to define eight major flow units within the entire system. The proportion of ice reaching Prydz Bay from the inner reaches of the system through the main trunk glacier, the Lambert, is only about $40 \%$, a figure further reduced by half if the gain in ice from basal freeze-on and snow accumulation is taken into account. Thus, a considerable proportion of the ice originates much more locally in ice streams that enter the Amery Ice Shelf in the north.

Reconstruction of particle paths for advanced grounded ice conditions suggests that most debris, which was deposited as diamictite at the inner and outer continental shelf drill sites, originated from the eastern side of the Lambert Graben, with little influence from the western side. The floor of the Lambert Graben also provided much of the material that makes up the diamictites at these sites. The inner continental seif sites were probably largely influenced by ice flowing off Princess Elizabeth Land, northeast of the Amery Ice Shelf. In times of reduced ice, as at the present day, little debris from the Prydz Bay hinterland may be deposited near the drill sites, and the main clastic component may be derived from icebergs that originate far to the east.
\end{abstract}

\section{INTRODUCTION}

In order to fully understand the depositional processes on the Prydz Bay continental shelf and to determine those that occurred in the geological past, it is necessary to consider how debris is transported through the Lambert Glacier-Amery Ice Shelf system and other ice masses bordering Prydz Bay. Although we lack both adequate outcrops of exposed rock to delineate source areas with confidence and paleocurrent data for determining transport paths, it is possible, using glaciological parameters, to make inferences concerning the origin and nature of the sediments on the continental shelf.

A variety of glaciological data has been published, but in terms of the dynamics of the Lambert Glacier-Amery Ice Shelf system there are conflicting ideas. Some authors have argued for surging, which if correct would have profound implications

1 Barron, J., Larsen, B., et al., 1991. Proc. ODP, Sci. Results, 119: College Station, TX (Ocean Drilling Program).

2 Alfred Wegener Institute for Polar and Marine Research, Columbusstraße, D-2850 Bremerhaven, Federal Republic of Germany (present address: Scott Polar Research Institute, University of Cambridge, Lensfield Road, Cambridge CB2 IER, UK). for the redistribution of debris. A key element in this study is determining the dynamics of the ice from its internal structure, thereby allowing us to define transport paths through the glacier system. Landsat satellite imagery, in which clear linear features on the ice surface can be observed, is used for this purpose. Such features have frequently been described as flow lines (e.g., Allison, 1979; Swithinbank, 1988, with reference to the Lambert Glacier). However, as Reynolds and Hambrey (1988) pointed out, they are not strictly flow lines. Rather they represent the surface expression of the three-dimensional structure, longitudinal foliation. Nevertheless, longitudinal-foliation is commonly (but not always) approximately parallel to flow, and detailed mapping of the structure, whether from the ground or from aerial or satellite sources, may permit it to be used for determining particle paths through the glacier system.

The purpose of this paper is to describe the contemporary glaciological setting of Prydz Bay and its hinterland and to present a structural glaciological map based on Landsat imagery. In particular, the controversial question as to whether surging behavior characterizes the glacier system will be examined, as this is important with regard to redistribution of debris. The information gleaned from satellite images is then used with reference to the geology of the hinterland in order to place constraints on debris sources for the Prydz Bay drill sites. 


\section{LAMBERT GLACIER-AMERY ICE SHELF SYSTEM}

\section{Ice Dynamics}

The Lambert Glacier-Amery Ice Shelf system is a composite feature, made up of several major confluent ice streams (Pl. 1, Fig. 1). The Lambert, Mellor, and Fisher glaciers originate farthest inland and form the main trunk glacier collectively known as the Lambert Glacier. However, in terms of ice frontage, by the time they reach the ice shelf edge in Prydz Bay, these glaciers are not the most important ones. Other ice streams join the main trunk glacier along its length, and several more join the ice shelf itself, notably the Charybdis Glacier from the west and a large ice stream ("Mawson Escarpment ice stream") from the east.

Ice-free areas include a prominent "oasis" in the northern Prince Charles Mountains. Here, a small branch of the Charybdis Glacier flows southward into a valley, at the end of which is Beaver Lake. Much rock is exposed in this area, which includes the only known sequence of sediments cropping out in this part of Antarctica.

There has been some debate concerning the state of balance of the Lambert Glacier-Amery Ice Shelf system, which is one of the world's largest glacier drainage basin. The entire system can be considered in three parts: the interior basin, the Lambert Glacier system, and the Amery Ice Shelf and its tributaries. For the interior basin the total mass flux was estimated by Allison (1979) as $60 \mathrm{Gt} \mathrm{a}^{-1}$. Outflow from the interior basin into the Lambert Glacier system was calculated to be only $30 \mathrm{Gt} \mathrm{a}^{-1}$, suggesting a buildup of ice upstream. Furthermore, from velocity and accumulation measurements, mass flux through a section near the boundary between the Lambert Glacier and Amery Ice Shelf was calculated to be only $11 \mathrm{Gt} \mathrm{a}^{-1}$. Losses through ablation in the Lambert Glacier system alone amount to $7 \mathrm{Gt}$ $\mathrm{a}^{-1}$, but this still leaves an overall excess mass of $12 \mathrm{Gt} \mathrm{a}^{-1}$ compared with the $30 \mathrm{Gt} \mathrm{a}^{-1}$ input. This also suggests steady contemporaneous build-up of ice in the basin, and therefore a propensity for surging.

A model for surging of the Lambert Glacier-Amery Ice Shelf system was developed by Budd and Mclnnes (1978). They considered that this, as well as other Antarctic drainage basins, may surge independently of each other. Their model indicated a periodicity of $23,000 \mathrm{yr}$ and that the time taken for the basin to reach its present state has been of the order of $12,000 \mathrm{yr}$. The duration of the major surges was shown to be $250 \mathrm{yr}$, with velocities reaching several kilometers a year. Budd and Mclnnes (1978) concluded that surging in the past may have been the rule rather than the exception.

The possibility that the Fisher Glacier has surged in the past was mentioned by Derbyshire and Peterson (1978) after a study of aerial photographs of the geomorphology on Mount Menzies. Further geomorphological evidence of surging was presented by Wellman (1982), who argued that the pattern of moraines bordering the Fisher Glacier was indicative of fluctuations in the ice level in a manner compatible with former surging behavior. The moraines indicate that at least three changes in altitude of ice level of Fisher Glacier have taken place, whereas other catchments in the Lambert Glacier-Amery Ice Shelf system have not. Wellman (1982) argued that these different moraine levels were a feature of periodically surging catchments, rather than to changes in the accumulation rate. However, no ground observations, nor any photographic documentation were presented in this study. Therefore, the data presented are inadequate to assess the validity of Wellman's (1982) claim that the Fisher is a surge-type glacier.

An alternative view considered that the system is essentially in a state of balance. Robin $(1979,1983)$ suggested that the ap- parent imbalance between discharge from the interior basin and inflow to the Lambert Glacier might be due to strong basal melting and only partial replacement of ice by basal freeze-on of oceanic ice, and that the accumulation rate may have been overestimated. Support for strong basal melting comes from oxygen isotope profile through the ice masses; it appears that $40 \%$ of the ice thickness of Lambert Glacier is absent at the outer shelf, and must have melted near the grounding line. McIntyre (1985a), using remote sensing techniques also concluded that no significant imbalance exists in the system. He redefined the interior drainage basin on the basis of Landsat imagery, established a reduced area of $902,000 \mathrm{~km}^{2}\left(1,090,000 \mathrm{~km}^{2}\right.$ according to Allison, 1979), and calculated the mass flux from it as $30 \mathrm{Gt} \mathrm{a}^{-1}$, almost balancing the input $\left(32 \mathrm{Gt}^{-1}\right)$. Figures for the Lambert Glacier system are the same as Allison's, but within the possible error range this part of the system could also be in balance. If McIntyre's reduced estimate of mass influx into the interior drainage basin is correct, then surging behavior would not be expected.

Subsequent correspondence (Allison et al., 1985; McIntyre, 1985b) has revealed little convergence of views, and resolution of the question concerning the state of balance of the system must come from better data, or from alternative methods of analysis. No direct indications of surging have been reported, and structural evidence presented in the following indicates that surging has not been a feature of ice currently residing within the Lambert Glacier-Amery Ice Shelf system. Despite the argument concerning the mass flux through the Lambert Graben, ice from the interior basin probably only contributes less than onehalf of the total ice entering Prydz Bay through the entire system, as discussed subsequently in this paper.

Surface velocity measurements of the Lambert Glacier system have been summarized by Swithinbank (1988); values at the thickness sounding locations plotted in Figure 1 are as follows. A velocity of $231 \mathrm{~m} \mathrm{a}^{-1}$ was measured where the ice is $1950 \mathrm{~m}$ thick in the Lambert Graben, $600 \mathrm{~km}$ from the ice shelf front, and at a place where bedrock is $840 \mathrm{~m}$ below sea level (mbsl). To the side of the main stream, where the ice is $800 \mathrm{~m}$ thick, a velocity of only $25 \mathrm{~m} \mathrm{a}^{-1}$ was recorded, whilst in ice covering a subglacial ridge to a depth of $430 \mathrm{~m}$, the velocity was $7 \mathrm{~m} \mathrm{a}^{-1}$. Velocities increase downstream toward the grounding line, near which a velocity of $347 \mathrm{~m} \mathrm{a}^{-1}$ was measured in ice $770 \mathrm{~m}$ thick.

Much of the Lambert Glacier, though not the Amery Ice Shelf, is an area of significant ablation, and meltstreams and lakes form on the glacier surface during the summer (Allison, 1979). Large areas of blue ice become exposed, and these clearly reveal the ice structure in satellite images. According to Allison (1979), the lower Lambert Glacier is probably sliding on its bed. The Lambert Glacier decouples from its bed some $300 \mathrm{~km}$ from the open coast and becomes the Amery Ice Shelf. The increasing surface velocities reflect an increasing longitudinal extending strain rate and thinning of the ice shelf (Budd et al., 1982). At the $640-\mathrm{m}$ ice depth sounding it is moving at $462 \mathrm{~m} \mathrm{a}^{-1}$, at the $380-\mathrm{m}$ sounding at $787 \mathrm{~m} \mathrm{a}^{-1}$, and in excess of $1200 \mathrm{~m} \mathrm{a}^{-1}$ at the centerline near the ice shelf front where the ice is only $270 \mathrm{~m}$ thick. Velocities have also been measured on two transverse profiles, one just north of the grounding line, the other up to within $65 \mathrm{~km}$ of the ice shelf seaward limit. These profiles show pronounced marginal shear for the inland site and more pervasive lateral shear across the outer part of the ice shelf. In the latter case velocities gradually decline toward near zero some distance from the true western margin of the shelf, suggesting a marginal zone of stagnant ice (Budd et al., 1982). Velocity measurements in the Amery Ice Shelf indicate that the flow lines diverge toward the seaward limit. For the main trunk glacier, this divergence amounts to about $17 \%$ (estimated from Fig. 1 of 


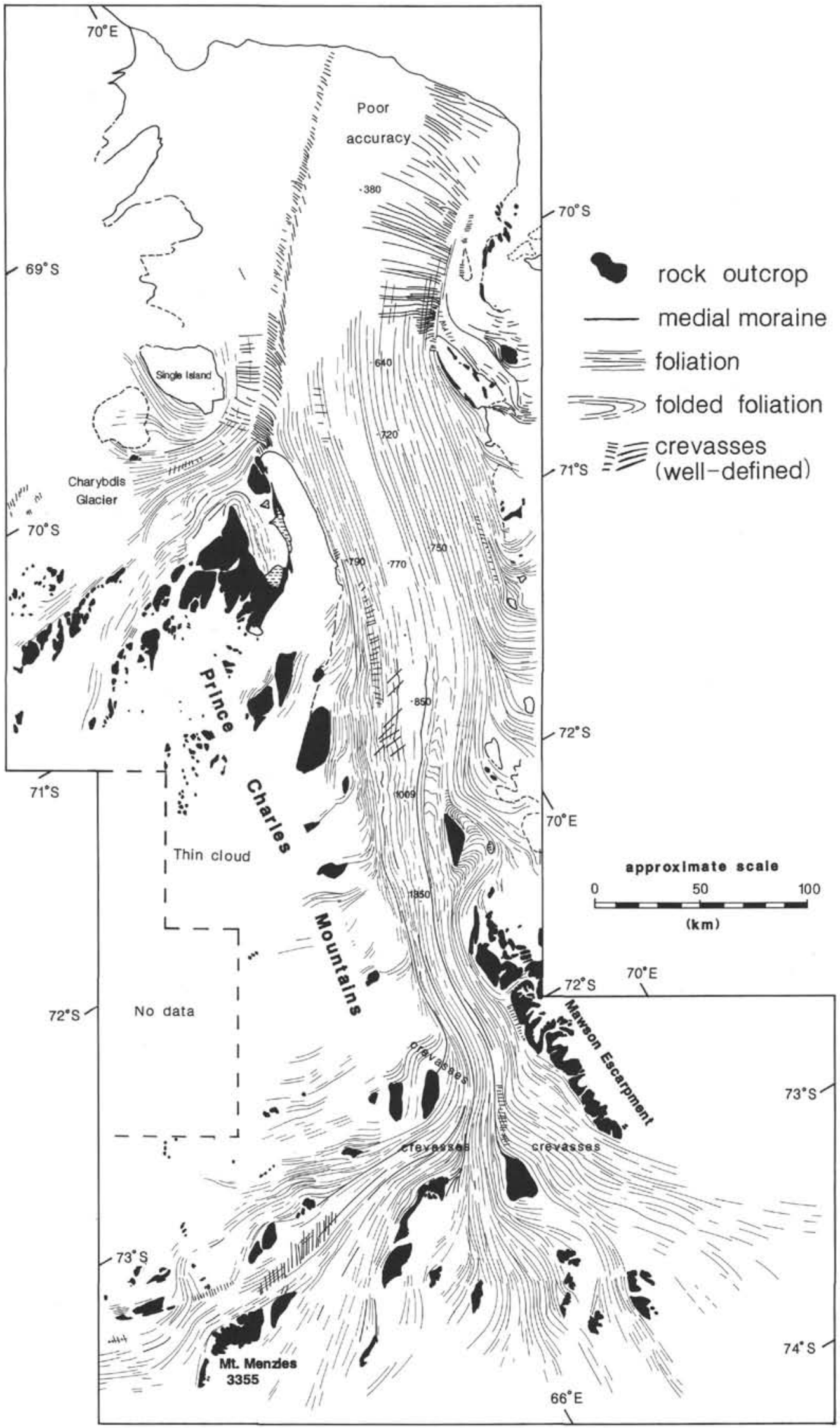

Figure 1. Structural glaciological map of the Lambert Glacier-Amery Ice Shelf system, based on Landsat images (see Table 1 for sources). Ice thicknesses in meters, based on seismic soundings, are from Swithinbank (1988). 
Budd et al., 1982). More pronounced divergence is depicted for the final $60 \mathrm{~km}$ to the edge of the ice shelf, but no data are presented to confirm this.

According to oxygen isotope studies on a core that penetrated through the outer Amery Ice Shelf, it has been estimated that some $40 \%$ of the ice mass is lost by basal melting close to the grounding line. One-third of this is replaced by basal freezeon of saline ice (Robin, 1983). This freeze-on process begins close to the grounding zone, with the result that a maximum thickness of $200 \mathrm{~m}$ from this source is acquired (Budd et al., 1982). Strain thinning seaward reduces this to about $110 \mathrm{~m}$ at the seaward limit. The implications of basal melting and freezeon for debris transport and sedimentation are highly significant: strong basal melting in the narrow zone between the grounding zone and the freeze-on position will release most basal debris, while the remaining debris will be transported out to the edge of the ice shelf and deposited in the marine environment from icebergs.

The northern half of the Amery Ice Shelf is an area of positive mass balance, which becomes more positive seaward. At the ice front, about $50 \mathrm{~m}$ of the total shelf thickness of $300 \mathrm{~m}$ is from snow that has accumulated in this area. Therefore, the proportion of the total thickness of ice derived from the Lambert Glacier system is less than one-half.

The Amery Ice Shelf front shows continual changes of position. Budd (1966) documented fluctuations over the period 1936-1965, and Swithinbank (1969) documented a major calving event that yielded $11,000 \mathrm{~km}^{2}$ of icebergs in 1963 . Today icebergs drift westward in the coastal current, and few from the Lambert Glacier-Amery Ice Shelf system pass over the Prydz Bay drill sites.

\section{Nature of Ice Cover in the Lambert Glacier-Amery Ice Shelf System}

The shape of the drainage basin is quite well defined on the basis of ice surface contours (Fig. 2). Flowlines, determined from surface slope data that were obtained by radio-echo sounding (Drewry, 1983), show a funneling effect into the Lambert Graben. The graben was defined on the basis of seismic (Stagg, 1985; Federov et al., 1982) and magnetic (Federov et al., 1982) data and continues out into the continental shelf.

The thickness of the ice cover is variable and tends to smooth out the underlying topography (Fig. 3). The ice is thinnest at the coast, with bare rock exposed in the Vestfold Hills and other localities between Davis Station and the Amery Ice Shelf; otherwise in coastal areas it is less than $500 \mathrm{~m}$ thick. Ice is also thin in elevated areas like the Prince Charles Mountains and Grove Mountains, where rock is exposed as nunataks. In the Lambert Graben ice reaches a thickness of $2500 \mathrm{~m}$ below Mawson Escarpment (Fig. 4), but this decreases northward to about $900 \mathrm{~m}$ at the grounding line and about $270 \mathrm{~m}$ at the ice shelf edge.

Elsewhere, the ice cover thickens inland, reaching its maximum of 3000-3500 $\mathrm{m}$ around the margins of the drainage basin. Anomalously thin areas of ice occur beneath Dome Argus where the Gamburtsev Subglacial Mountains are totally buried by ice (Fig. 3). Seismic soundings made in this area by Soviet scientists indicate ice thicknesses as low as $600 \mathrm{~m}$ (Swithinbank, 1988).

\section{Bedrock Topography Beneath the Lambert Glacier-Amery Ice Shelf System and Prydz Bay}

The topography of the submarine floor of Prydz Bay is characterized by a general deepening coastward from less than 500 $\mathrm{m}$ at the continental shelf break to over $1000 \mathrm{~m}$ in places near the coast (Fig. 1 in Hambrey et al., this volume; Cooper et al., this volume). This is the Amery Basin and its character resembles that of many other parts of the Antarctic continental shelf. A number of banks lie in the outer parts of the bay, of which the Four Ladies Bank in the northeast is the most prominent; it rises to within $200 \mathrm{~m}$ of sea level and is scoured by icebergs. Prydz Bay is crossed by a broad transverse channel, the Prydz Channel that reaches the continental shelf break at the head of a large trough mouth fan. A narrow channel, the Svenner Channel, runs parallel to, and about $40 \mathrm{~km}$ from, the coast of Princess Elizabeth Land, extending northeast from the Amery Ice Shelf for $180 \mathrm{~km}$. It is joined by the Rauer Deep to the southwest of Davis Station. Another deep channel extends northward from the western margin of the Amery Ice Shelf. Further details about the bathymetry of Prydz Bay are given elsewhere (Cooper et al., this volume; Hambrey et al., this volume).

The subglacial topography is known in broad terms mainly from radio-echo sounding (Drewry, 1983) (Fig. 5). The deep trench of the Lambert Graben is bordered by high ground to the west, east, and south. From the seaward edge of the Amery Ice Shelf, the Amery Basin continues to deepen progressively southward under the ice shelf and the Lambert Glacier, finally reaching a depth of at least 2500 mbsl (Fig. 4).

The graben is bordered to the west by a partially exposed mountain complex, the Prince Charles Mountains, which in Mount Menzies attains a maximum height of $3355 \mathrm{~m}$ above sea level. Several tributary trenches cut through these mountains and enter the main Lambert Graben. The eastern margin is defined by a pronounced, largely continuous, straight escarpment, rising to over $1000 \mathrm{~m}$ above sea level and cropping out as the Mawson Escarpment in the south. With over $2500 \mathrm{~m}$ of ice in the graben, the true relief of this eastern margin is of the order of $3000 \mathrm{~m}$. East of the escarpment, geomagnetic data (Federov et al., 1982) indicate the existence of a branch of the main graben. This is largely sediment-filled, but it acts as a major drainage route for ice from the Grove Mountains that rise to more than $1500 \mathrm{~m}$ farther to the east and that project through the ice as small nunataks. The Grove Mountains are just a small surface expression of a large elevated subglacial land mass, $1000-1500 \mathrm{~m}$ high, that forms much of Princess Elizabeth Land.

At the head of the Lambert Graben is a north-northwesttrending subglacial mountain mass, mainly above $1500 \mathrm{~m}$, which serves as a ridge, on either side of which ice flow is directed (Fig. 5). The southern extremity of this mass culminates in the Gamburtsev Subglacial Mountains, which rise to more than $3000 \mathrm{~m}$ above sea level and are overlain by Dome Argus. Lower, but nevertheless elevated, areas connect this area with the southwestern Prince Charles Mountains and Grove Mountains. Penetrating these masses are subsea-level feeder branches of the Lambert Graben, one of which penetrates nearly $1000 \mathrm{~km}$ southward from the edge of the Amery Ice Shelf. Various other low-altitude basins complete this rather complex topographic picture. Over much of the region ice smoothes out the underlying topography, but apart from the general movement of ice into the Lambert Graben, ice surface flow is not strongly controlled by the irregularities of the bedrock.

\section{GEOLOGY OF THE PRYDZ BAY HINTERLAND}

In order to examine potential sources of sediment from the Prydz Bay drill sites we need to consider both the relatively small area of exposed rocks and the rocks that are inferred from geophysical data to underlie the ice cover.

Exposed rocks, which extend $600 \mathrm{~km}$ poleward from the coast, are most widespread in the Prince Charles Mountains (including Mawson Escarpment) and the Vestfold Hills near Davis Station. Most outcrops consist of igneous and metamorphic rocks of Precambrian age. Soviet and Australian geologists have interpreted these rocks in quite different ways. The former have considered that, broadly, the rocks become increasingly metamorphosed as they become older (Ravich et al., 1984), whereas 


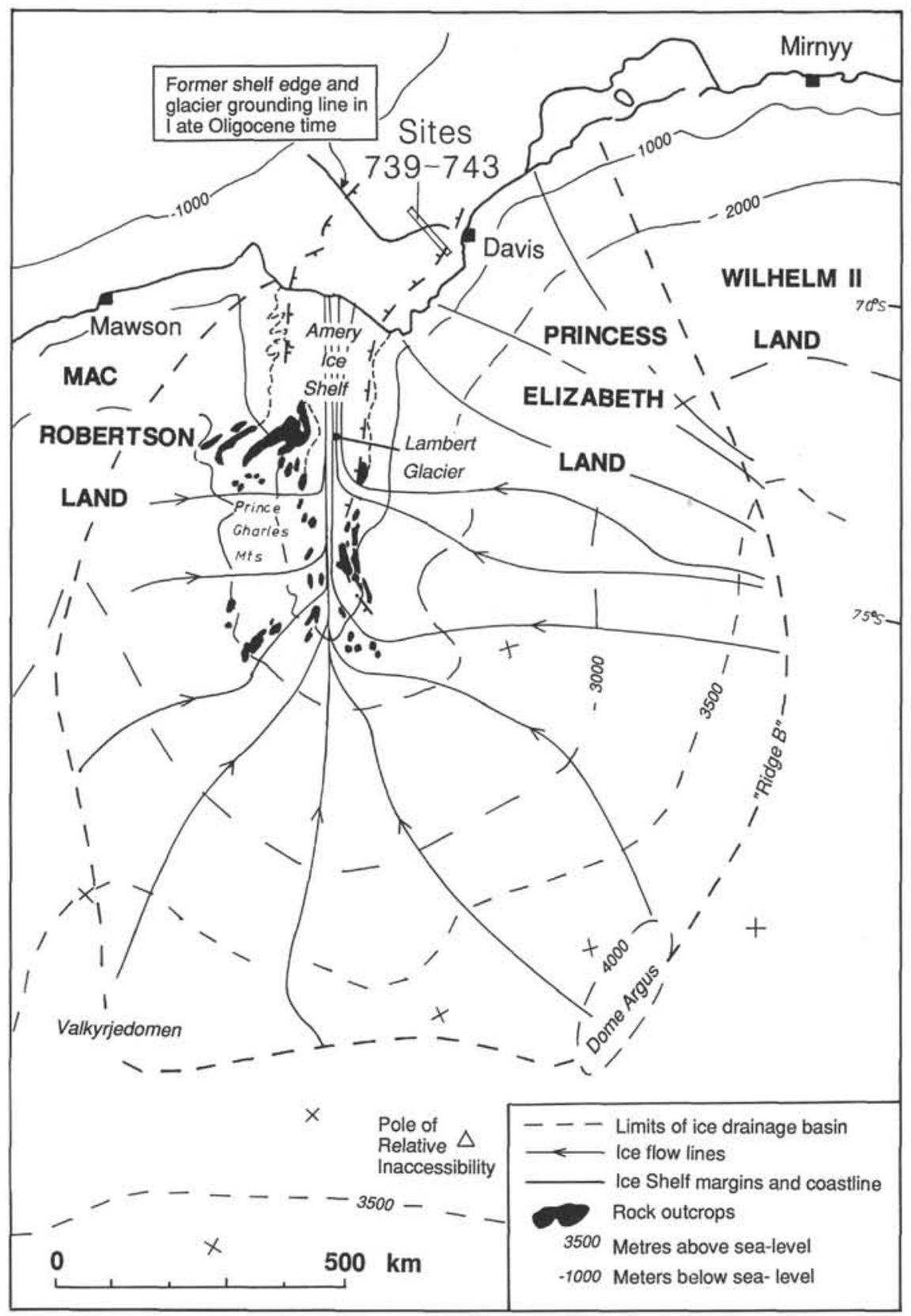

Figure 2. The Lambert Glacier-Amery Ice Shelf drainage basin and its ice flowlines (after Drewry, 1983). ODP drill sites and the portion of shelf break in early Miocene are indicated.

the Australians, on the basis of geochronological investigations, have suggested that the lower grade rocks exposed in the southern Prince Charles Mountains are Archean and that the highest grade rocks are of late Proterozoic age (Tingey, 1982) (Fig. 6). The sequence of older rocks according to Tingey (1982) is:

1. Archean granitic basement with mainly massive or poorly foliated gneisses exposed in the southern Prince Charles Mountains and Vestfold Hills (Oliver et al., 1982);

2. Archean metasediments with fuchsite-bearing quartzite, conglomerate, psammite, calc-silicate rocks, iron-rich strata, and para-amphibolite; and

3. Proterozoic pegmatite, granite, migmatite, retrogressed amphibolite, slate, shale, minor quartzite, and banded iron-formations.
The Archean to middle Proterozoic rocks are intruded by supposed middle Proterozoic amphibolitized tholeiitic dikes and by unmetamorphosed granite and pegmatite of probable Cambrian age. Late Proterozoic metamorphism to granulite and upper amphibolite facies took place in the northern Prince Charles Mountains, with metamorphic grade decreasing southward.

Of these rocks, the most distinctive and potentially most useful as tracers are the fuchsite-bearing quartzite (Tingey, 1982) and the banded iron-formations of the southwestern Prince Charles Mountains (Ravich et al., 1982, 1984). The banded iron-formations have been traced geomagnetically for $120 \mathrm{~km}$ beneath the ice near the head of Fisher Glacier, and should thus be well represented in some of the ice reaching Prydz Bay.

Younger sedimentary strata are exposed in the Beaver Lake area of the northern Prince Charles Mountains (Mond, 1972; 


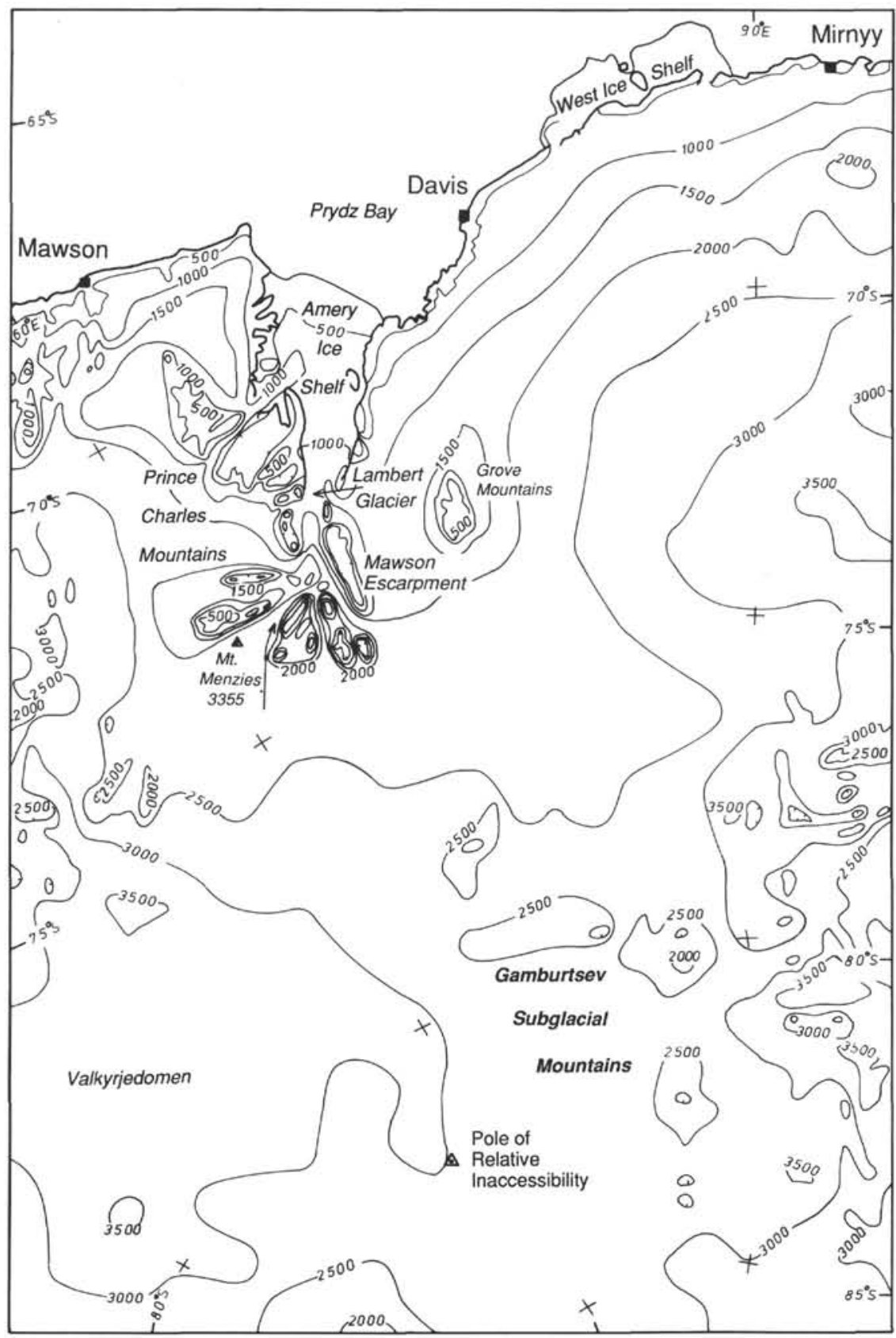

Figure 3. Ice thickness contours (in meters) in the Lambert Glacier-Amery Ice Shelf drainage basin (after Drewry, 1983).

Tingey, 1982; Ravich and Federov, 1982). Here a Permian sequence, the Amery Group, which is analogous to the Beacon Supergroup of the Transantarctic Mountains, comprises three units from bottom to top (Ravich and Federov, 1982; Ravich et al., 1984):

1. $250 \mathrm{~m}$ of conglomerate, gritstone, coal-siltstone, and shale;

2. $900 \mathrm{~m}$ of rhythmically bedded sandstone, siltstone, claystone, and $2 \mathrm{~m}$-thick coal seams; and

3. $200 \mathrm{~m}$ of arkose, coarse sandstone, fine sandstone, and claystone.

The total outcrop area of Permian sediments is $450 \mathrm{~km}^{2}$. No other sedimentary strata, apart from Cenozoic tills, are exposed in the region, but a red siltstone of Permian age was found in moraine in the southern Prince Charles Mountains (Ravich et al., 1984).

Despite the relatively small outcrop area of Permian and younger strata, much of the region is believed to be underlain by such sediments, principally in the complex graben structure occupied by the Lambert Glacier-Amery Ice Shelf system. The Lambert Graben is a structure that extends south for almost 700 $\mathrm{km}$ and shows present-day bedrock relief, mainly subice, of as much as $3500 \mathrm{~m}$ (Federov et al., 1982). Magnetic data have revealed depressions $5 \mathrm{~km}$ or more in depth in the basement, filled with nonmagnetic rocks. Deep seismic soundings indicate deep faults bounding the graben, with marked crustal thinning beneath. The basement is deepest $(>5 \mathrm{~km})$ under the northern 

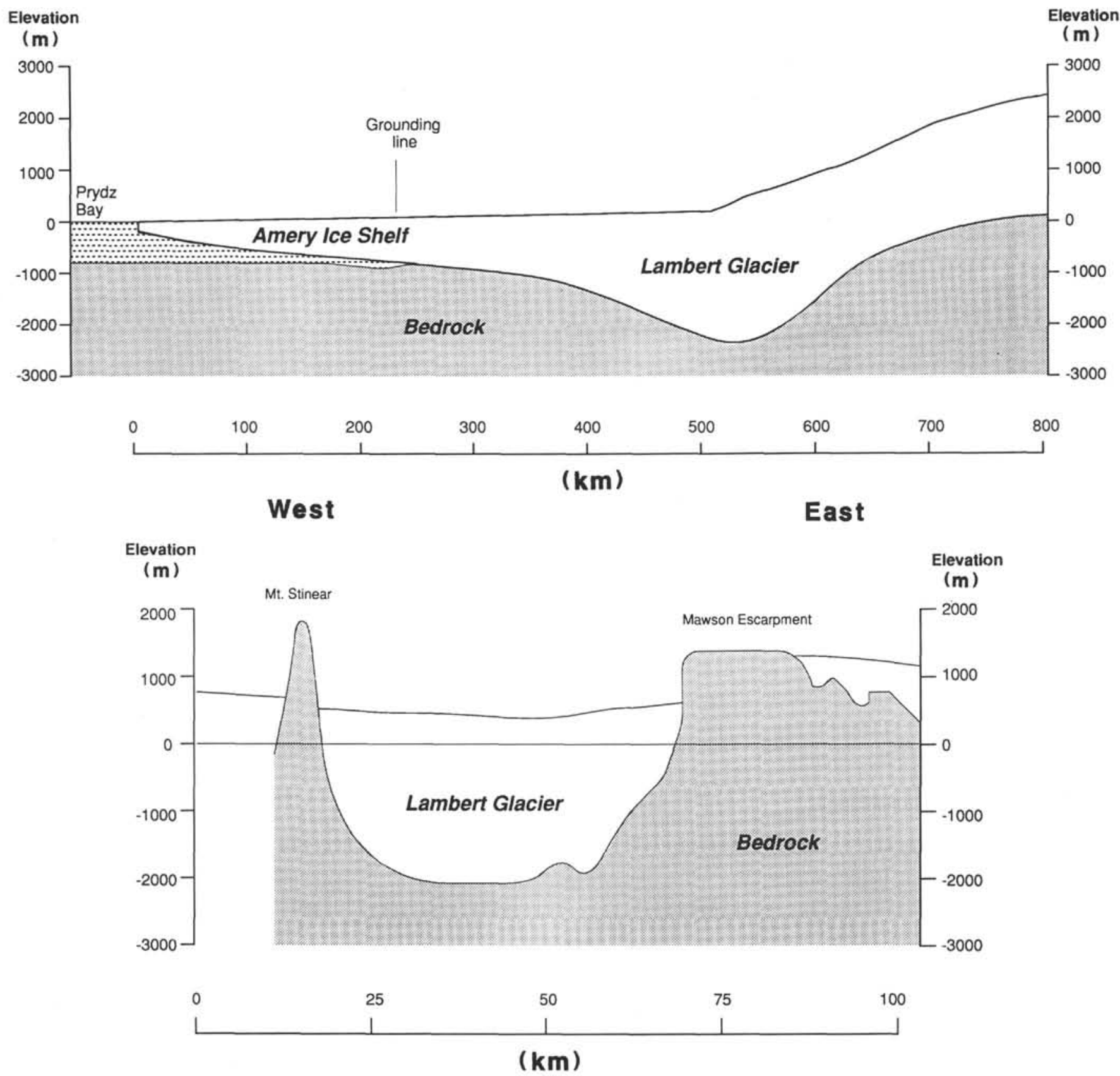

Figure 4. Longitudinal profile (top) through the Lambert Glacier and Amery Ice Shelf, and cross-section (bottom) through the Lambert Glacier in the region of Mawson Escarpment, based on radio-echo sounding data (after Morgan and Budd, 1975).

part of the Lambert Glacier-Amery Ice Shelf and Prydz Bay. Deep basement depressions occur on either side of Mawson Escarpment. The depression on the east side is filled with nonmagnetic material; it contains more sediment than the main graben, and the ice is correspondingly thinner. The western depression has been strongly overdeepened by ice (Fig. 4), over a distance of at least $400 \mathrm{~km}$, especially below Mawson Escarpment. Assuming an originally regular valley bottom profile, at least $14,000 \mathrm{~km}^{3}$ of sediment has been removed. This figure is likely to be much greater if the inferred erosion of up to $1 \mathrm{~km}$ depth on the continental shelf (Solheim et al., this volume) is extrapolated back into the valley.

There is also a southerly continuation of the smaller graben containing Beaver Lake and the associated Permian sediments exposed there. In addition, a basement depression about $3 \mathrm{~km}$ deep, containing nonmagnetic rock, occurs within a graben that is occupied by Charybdis Glacier.

The timing of development of the graben complex is uncertain. Federov et al. (1982) suggested that the main rifting began in late Mesozoic time, with migration of tectonic activity westward with time. Stagg (1985) considered two possibilities based on the interpretation of seismic sequences in Prydz Bay: Permian to Late Jurassic, or Early Cretaceous, with the break-away of India from Antarctica taking place in Triassic-Early Jurassic time.

In Prydz Bay, seismic surveys show a northerly extension of the Lambert Graben (Stagg, 1985), although eastern Prydz Bay, where the drill sites are located, may not be directly along the 


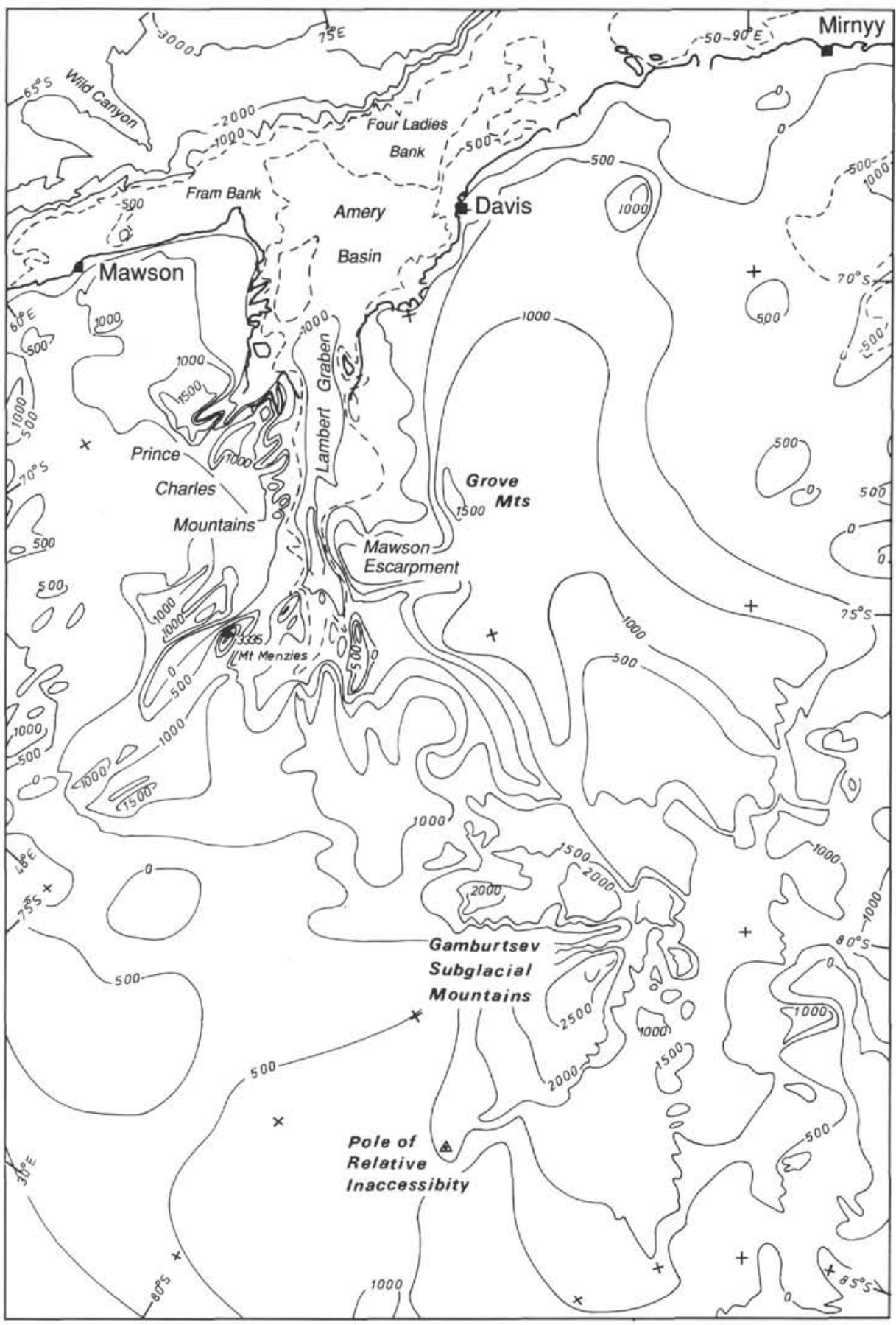

Figure 5. Bedrock elevation contours beneath the ice cover of the Lambert Glacier-Amery Ice Shelf system and on the continental shelf (after Drewry, 1983).

line of the graben. The sedimentary packages of the continental shelf are predominantly continental in the inner part (Turner et al., this volume) and terrestrial-marine glacigenic in the outer part (Hambrey et al., this volume), and these sediments would have largely been derived from the hinterland of Prydz Bay. Whatever the precise timing and initiation of the formation of the Lambert Graben, it has been the dominant control on ice movement in the region ever since ice first reached Prydz Bay.

\section{STRUCTURAL GLACIOLOGY OF THE LAMBERT GLACIER-AMERY ICE SHELF SYSTEM}

\section{Satellite Imagery}

Few structural studies of Antarctic glaciers have been undertaken. Nevertheless, Landsat imagery reveals structural detail in much of the Antarctic Ice Sheet, which can be useful in interpreting the flow dynamics and particle paths through the ice 


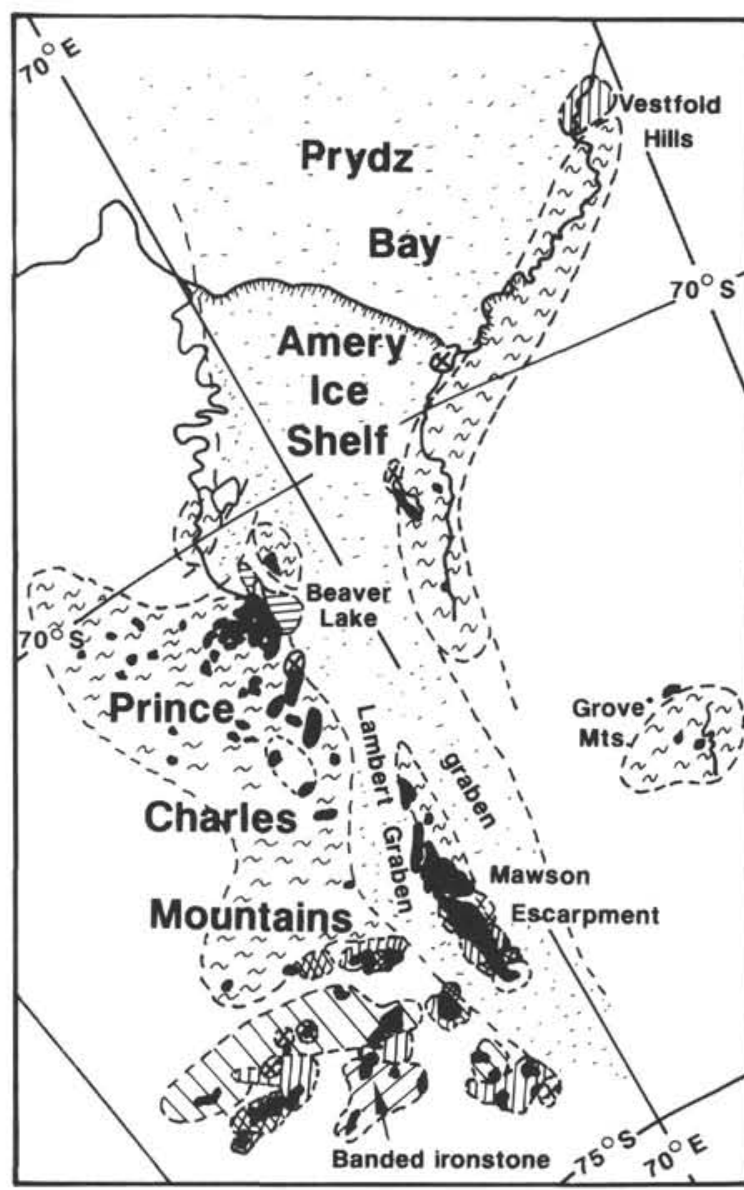

Wind Undferentiated graben sediments

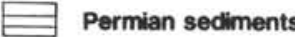

$x \times$ Cambrian acid intrusives

Late Proterozoic metamorphics
Late Proterozoic metasediments

28 Archean metasediments

Archean basement

Rock outcrops

Figure 6. Summary geological map of the Prydz Bay hinterland (after Tingey, 1982; with additional data on graben-fill sediments from Ravich et al., 1984).

mass. Longitudinal linear features, which most glaciologists refer to over-simplistically as flowlines, are characteristic of many parts of the Antarctic Ice Sheet (see Swithinbank, 1988, for many examples). However, a flowline cannot be a physical entity; rather we are observing the surface manifestation of the three-dimensional structure of the ice.

Recent work on ice shelves in the Antarctic Peninsula (Reynolds and Hambrey, 1988; Reynolds, 1988) has demonstrated the utility of Landsat imagery in interpreting ice structures and dynamics. Ground observations of exposed structures on the George VI Ice Shelf give us confidence that the interpretations of Landsat images are reasonable.

Satellite imagery covering the Lambert Glacier-Amery Ice Shelf system dates mainly from 1973 and 1974 (Table 1) and is of variably quality. Images with good structural resolution (Pl. 1) cover the main trunk of the Lambert Glacier, north of its confluence with the Mellor and Fisher glaciers and extend to the middle part of the Amery Ice Shelf. The structure is especially clear because large expanses of the glacier comprise bare ice.

Resolution of structures in the outer Amery Ice Shelf and coastal areas is poor, because of snow cover, although large crevasse systems are prominent.
Table 1. List of Landsat 1 MSS images used in the preparation of the structural map (Fig. 1).

\begin{tabular}{lllll}
\hline Image no. & Bands & Path & Row & \multicolumn{1}{c}{ Date } \\
\hline $1580-03205$ & 7 & 137 & 109 & 23 February 1974 \\
$1236-03150$ & $4,5,7$ & 135 & 110 & 16 March 1973 \\
$1580-03211$ & $4,5,7$ & 137 & 110 & 23 February 1974 \\
$1236-03153$ & $4,5,7$ & 135 & 111 & 16 March 1973 \\
$1236-03155$ & $4,5,7$ & 135 & 112 & 16 March 1973 \\
$1130-03270$ & 6.7 & 137 & 112 & 30 November 1972 \\
$1162-03041$ & 6,7 & 133 & 113 & 1 January 1973 \\
$1196-02530$ & $4,5,7$ & 131 & 113 & 4 February 1973 \\
$1196-02521$ & $4,5,7$ & 131 & 111 & 4 February 1973 \\
$1577-03045$ & $4,5,7$ & 134 & 112 & 20 February 1974 \\
\hline
\end{tabular}

Note: These are digitally enhanced in false color and composited from Bands 4,5 , and 7 by the U.S. Geological Survey Processing Facility at Flagstaff. The last image in this list is illustrated as Plate 1. Additional images used are illustrated in Swithinbank (1988). 


\section{Description of Structures}

\section{Foliation}

The dominant structure of the Lambert Glacier-Amery Ice Shelf system is a longitudinal foliation (Fig. 1 and Pl. 1). This type of structure invariably forms at the margins of a flowing ice mass and, in constrained channels, commonly also pervades the entire width of a glacier (Hambrey, 1977; Hambrey and Müller, 1978). Foliation of this type is generally of near-vertical orientation and defined by intercalating layers of ice of varying crystal size and bubble content on a scale of centimeters to meters. Groups of foliae can be traced for hundreds of meters or kilometers, therefore being visible in Landsat images (cf. Reynolds and Hambrey, 1988; Reynolds, 1988). Commonly, longitudinal foliation forms parallel to, and is intimately associated with, medial moraines, as in the present case. Thus, boundaries between individual tributaries can be followed for much of the length of the glacier, thereby defining flow units.

Changes in the geometry of the Lambert Glacier channel and the entry of tributary glaciers are reflected in modifications to the dominant structure. Before entering the main stream, most tributaries are flowing in increasingly constrained channels. Longitudinal foliation in these individual tributaries becomes strongly attenuated as the main stream is joined, and this characteristic, combined with the convergence of moraines, indicates reduction in width of the individual flow units by a factor of five times or more. Downstream, the longitudinal foliation in all tributaries is bent sharply to the north as it enters the main channel. The foliation is generally strongest in the most constrained channels; this is especially noticeable downstream of the confluence of the Lambert, Mellor, and Fisher glaciers (Pl. 1).

The Lambert Glacier valley opens out north of the Mawson Escarpment around latitude $72^{\circ} \mathrm{S}$. The eastern part of the Lambert Glacier flow unit passes in a loop around a nunatak (the Clemence Massif), joins part of another ice stream descending north of the Mawson Escarpment, before rejoining the main stream. The longitudinal foliation that enters this loop develops a transverse, then strongly arcuate orientation. As it rejoins the main stream the arcuate structure becomes increasingly attenuated and transposed back into a longitudinal structure (Fig. 1).

West and northwest of this nunatak, the longitudinal foliation in the Lambert Glacier flow unit also becomes deformed, developing a draglike fold structure against the western margin of the flow unit, with fold axes parallel to the valley sides. For $80 \mathrm{~km}$ downstream, this fold structure gives a transverse attitude to the foliation in part of the Lambert Glacier flow unit.

In the adjacent flow units (the continuations of the Mellor and Fisher glaciers), the longitudinal foliation develops low-amplitude folding, but with fold axes normal to the main stream. The groups of foliae become wider, a further indication of lateral spreading or longitudinal compression. This zone extends for some $100 \mathrm{~km}$ as far as the grounding line.

Downstream of the grounding line, now in the Amery Ice Shelf, the regular parallel nature of the longitudinal foliation is restored as further large ice streams, each with their own longitudinal foliation, join the ice shelf. One exception to this is that a branch of the Charybdis Glacier spalls off and flows south into the oasis area of Beaver Lake. The longitudinal foliation here splays out slightly, but is lost amongst an intensively crevassed area, generated as the ice tongue breaks up on floating.

\section{Crevasses}

The satellite images do not all clearly show the crevasse systems, but the best defined are plotted in Figure 1. Particularly dense, but poorly resolved, crevasse networks occur in the Fisher, Mellor, and Lambert glaciers as they become narrower toward their confluence with each other (PI. 1). Individual crevasses here are short and of variable orientation and appear to break up the entire glacier surface into small blocks. Below the confluence of these three glaciers, the Lambert Glacier is relatively crevasse-free, as indicated by the presence of a well-developed network of supraglacial lakes and streams.

The most prominent crevasses are in the Amery Ice Shelf. The eastern margin shows a set of enormous fractures, the biggest of which is $45 \mathrm{~km}$ long (Fig. 1). These crevasses form in the main ice stream, near-normal to the margin of the flow unit (i.e., perpendicular to the longitudinal foliation), but they end abruptly against ice entering the northeasternmost part of the ice shelf, just north of Gillock Island. Another set of shorter (10 km long) crevasses are orientated at $45^{\circ}$ to the longitudinal foliation trend and have developed in the ice at the eastern margin of the Charybdis Glacier (Fig. 1).

\section{Supraglacial Debris}

The amount of debris carried at the surface of the Lambert Glacier-Amery Ice Shelf system is limited. Satellite images (PI. 1) show thin lines of debris parallel to longitudinal foliation extending downstream from the confluences of Mellor Glacier with both the Fisher and Lambert glaciers and a thicker line of debris on the western side of the Fisher Glacier flow unit. None of these debris lines is traceable all the way to the snout on the satellite images.

The rate of supply of angular material onto the surface of the Lambert Glacier-Amery Ice Shelf system is thus minor at the present day. The bulk of the debris transport must therefore be at the base of the ice mass.

\section{Supraglacial Drainage}

In the crevasse-free zones of the main trunk ice stream of the composite Lambert Glacier, several large meltwater streams are visible in the satellite images, flowing approximately parallel to the longitudinal foliation. In addition, meltwater lakes are prominent in the middle of the glacier below Mawson Escarpment (P1. 1). Farther north, around $71^{\circ} 30^{\prime} \mathrm{S}$, in the western part of the glacier as it approaches the grounding line, much of the ice surface is covered by long linear lakes parallel to the foliation. None of the water on the surface of the glacier plays a significant role in recycling debris. Even though much of the meltwater may reach the base of the glacier eventually, it will be carrying little debris and thus have little influence on eventual sedimentation.

\section{Origin of Foliation}

The origin of the longitudinal foliation cannot be demonstrated in these satellite images as it is already developed when it first makes its appearance as the ice descends from the Polar Plateau. Previous work has demonstrated that foliation normally is derived from earlier structures as a result of transposition (Hooke and Hudleston, 1978; Hambrey, 1975, 1977). This process is especially prevalent where flat-lying stratification in wide accumulation areas is funnelled into a narrow channel. As a result of large- and small-scale isoclinal folding, the primary layering is almost totally transposed into a vertical foliation, orientated parallel to the margins (e.g., as in White Glacier, Canadian Arctic; Hambrey and Mller, 1978). This seems to be the most likely explanation for the foliation in the Lambert GlacierAmery Ice Shelf system.

\section{Flow Pattern and Particle Paths Derived from Structure}

\section{Present-Day Flow}

The longitudinal foliation and associated medial moraines generally define the individual flow units within the glacier sys- 
tem. Changes in the cross-sectional width of the flow units can be clearly identified, at least as far north as $70^{\circ} \mathrm{S}$. The longitudinal foliation and moraines represent particle paths through the glacier system. Mostly the foliation is likely to be parallel to velocity vectors or "flowlines," but exceptions occur, for example, where the longitudinal foliation is deformed around a nunatak and becomes transverse. The regular nature of the foliation suggests that the Lambert Glacier and all its tributaries have been in steady state within the residence time of ice in the entire system.

The low-amplitude folding of the longitudinal foliation, which occurs as the ice approaches the grounding line and spreads laterally, is an indication of longitudinal compression. North of $70^{\circ} \mathrm{S}$, the entry of the Charybdis Glacier from the west creates a major shear zone, marked by a series of en echelon crevasses. The crevasses have formed within Charybdis ice, at an angle of $90^{\circ}$ to the margin as it comes into contact with the rest of the Amery Ice Shelf (Fig. 1). The crevasses rotate and bend as the ice flows north to an angle of $135^{\circ}$ or more over a distance of about $80 \mathrm{~km}$. Thereafter, the crevasse orientation is fairly consistent. This changing geometry and strong development of these crevasses suggests that Charybdis ice is flowing considerably faster than Lambert Glacier and associated ice at the point of confluence, but as the crevasses cease to rotate from $80 \mathrm{~km}$ onward, the velocities are equalized. By the time the transverse profile $50-60 \mathrm{~km}$ from the ice shelf front is reached, the whole system behaves as a single flow unit, with peak velocity in the ice that enters through the Lambert Glacier system.

The eastern margin of the main composite ice stream is defined by the huge transverse crevasses that are developed from Gillock Island northward to the seaward edge of the ice shelf. A major flow discontinuity is suspected at this position, and the crevasses further indicate rapid extension as the ice accelerates seaward.

Both these major crevasse systems demarcate the boundaries of the flow units that join the Amery Ice Shelf in this northern area. They show that there is a slight increase in the width of the composite Lambert flow unit, although not as much as implied by the flowlines drawn from velocity vectors (Budd et al., 1982). Extrapolation of the longitudinal foliation from the inner Amery Ice Shelf between the major crevasse systems is easily achieved and enables us to define approximately the boundaries of the individual flow units as far as the ice shelf calving limit.

Structural interpretation of the Lambert Glacier-Amery Ice Shelf system has enabled eight major flow units to be defined (Fig. 7). Their relative importance on the Prydz Bay marine environment can be assessed by determining their mass flux on the basis of:

1. The width of each flow unit as it passes through the Amery Ice Shelf transverse profile, $50-60 \mathrm{~km}$ from the ice front;

2. The mean velocities of flow units on this profile estimated from Budd et al. (1982); and

3. Assumption of a constant ice thickness across the whole shelf (estimated from Budd et al., 1982).

The most important flow units are those derived from the Charybdis and Mellor glaciers, and the Mawson Escarpment ice stream, each representing about one-fifth of the mass flux through the profile (including the ice acquired by basal freezeon below the ice shelf and accumulation on top) (Table 2). The proportion of ice from the southern Prince Charles Mountains and the interior basin, including the Gamburtsev Subglacial Mountains, is only $42 \%$. The dominant sources of ice reaching Prydz Bay are therefore in the northern areas, reflecting greater precipitation toward the coast and ablation in the Lambert Glacier system.

\section{Delineation of Flow Units during Phases of an Expanded Ice Shelf}

It is assumed that the flow units will remain of constant width in an expanded floating ice shelf. The marked divergence today postulated by Budd et al. (1982) downstream of the northern transverse Amery Ice Shelf profile is not in evidence structurally. Taking into account the present configuration of the Prydz Bay coastline, the location of the shelf break, and the supposed influence of flanking glaciers, it is expected that flow units will curve to the west and approach the mouth of the bay at right angles (Fig. 7). Those in the middle of the ice shelf will have been faster moving compared with those near the margins and therefore are more effective at transporting debris into Prydz Bay. Although rather speculative, such behavior would be in conformity with that of other ice shelves in Antarctica today, such as in the examples illustrated by Swithinbank (1988). Thus the inner Prydz Bay Sites 740 and 741 would probably have been influenced mainly by ice flowing off the coast southwest of Davis Station, whereas the other sites would have been influenced by ice originating in the southern Prince Charles Mountains (or in the case of Site 742) possibly also the Grove Mountains.

\section{Delineation of Flow Units with Ice Grounded to the Continental Shelf Edge}

Because of the complexity of the Prydz Bay bottom topography, it is difficult to predict the geometry of the flow units as grounded ice expanded across the bay to the continental shelf break. In comparison with other areas, notably Malaspina Glacier in Alaska, ice may have fanned out as a piedmont lobe, with strong folding of the flow units perpendicular to their lengths. The position of the Prydz Bay trough mouth fan (Fig. 7) suggests that ice flow may have been focused through the broad Prydz Trough and western marginal trough, that is, west of the predicted median line of a floating ice shelf. Some preferential ice flow may have occurred through the Svenner Channel, parallel to the coast of Princess Elizabeth Land, but this is most likely to have been local ice, rather than ice from the Lambert Graben. With ice grounded to the shelf edge, therefore, Prydz Bay Sites 742,739 and 743 were probably influenced by ice originating from the eastern side of the graben and from the Grove Mountains and Gamburtsev Subglacial Mountains farther inland.

\section{DISCUSSION}

\section{Transport Paths of Debris Through the Lambert Glacier-Amery Ice Shelf System}

In steady state glaciers it is normally possible to trace the trajectories of debris to the depositional site, because the particle paths in the ice are normally parallel or diverge or converge in a predictable manner according to the shape of the confining channel. Thus, debris will remain on one side of the glacier as it is transported downstream. This aspect of glacier flow has frequently been applied to formerly glacierized areas in order to reconstruct ice sheet dynamics.

An exception to this rule is the effect on debris distribution induced by surging glaciers. Although there is no documented example of unequivocal surging in Antarctica, it has been argued that as the net accumulation rate of ice in Antarctica seems to be greater than the loss of mass, the ice sheet may become unstable and large parts of it may surge (Hollin, 1969; Budd and McInnes, 1978).

If, as has been suggested, the Lambert Glacier-Amery Ice Shelf system is prone to surging, then prediction of paleo-transport paths of debris would be almost impossible. For example, 


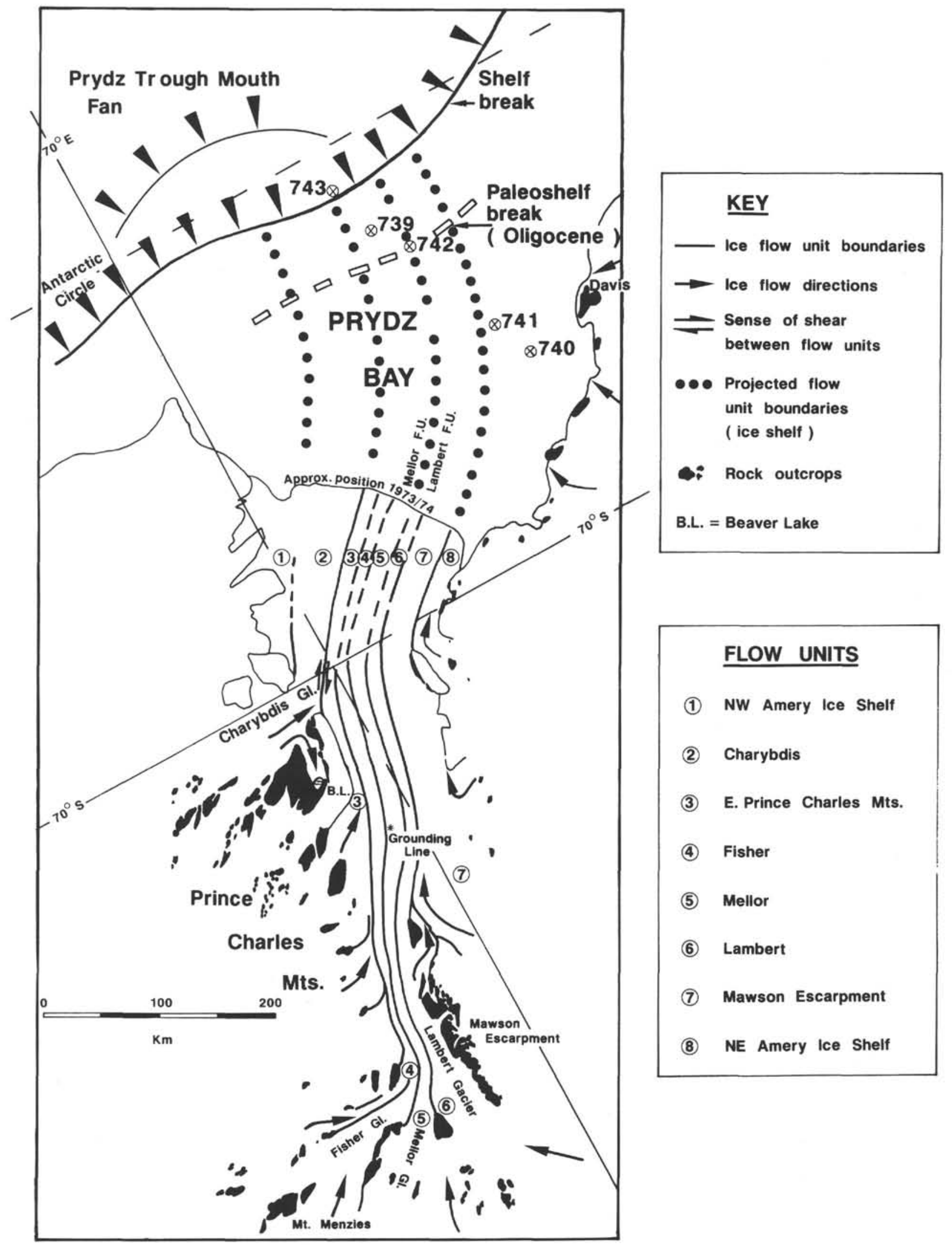

Figure 7. Map of the principal flow units of the Lambert Glacier-Amery Ice Shelf system derived from the structural map in Figure 1. Hypothetical continuations of the flow units are shown for an expanded ice shelf in relation to the drill sites and major bathymetric features in Prydz Bay. Position of early Oligocene paleo-shelf break is from Cooper et al. (this volume). 
Table 2. Approximate widths of ice flow units, estimated velocity, and mass flux on the Amery Ice Shelf Project traverse from Depot E to A119, that is, approximately normal to the flow direction, and $50-60 \mathrm{~km}$ from the ice shelf front.

\begin{tabular}{|c|c|c|c|c|c|}
\hline \multirow[b]{2}{*}{ Individual flow units } & \multirow{2}{*}{$\begin{array}{c}\text { Approximate } \\
\text { width }(\mathrm{km})\end{array}$} & \multicolumn{2}{|c|}{ Velocity $(\mathrm{m} / \mathrm{yr})$} & \multicolumn{2}{|c|}{ Mass flux } \\
\hline & & Range & Mean & $\mathrm{km}^{3} / \mathrm{yr}$ & Percent of total \\
\hline 1. Northwestern ice shelf & 29 & Low & ? & Minor? & Excluded \\
\hline 2. Charybdis & 44 & $0-510$ & 300 & 4.7 & 19 \\
\hline 3. Eastern Prince Charles Mountains & 13 & $650-710$ & 680 & 3.2 & 13 \\
\hline 4. Fisher & 11 & $710-750$ & 730 & 2.9 & 11 \\
\hline 5. Mellor & 19 & $710-780$ & 735 & 5.0 & 20 \\
\hline 6. Lambert & 11 & $660-710$ & 685 & 2.7 & 11 \\
\hline 7. Mawson Escarpment & 27 & $390-660$ & 525 & 5.1 & 21 \\
\hline 8. Northeastern ice shelf & 17 & $0-390$ & 210 & 1.3 & 5 \\
\hline Totals & 171 & & & 24.9 & 100 \\
\hline \multicolumn{6}{|l|}{ Combined flow units ${ }^{a}$} \\
\hline Southern Prince Charles Mountains (4-6) & & & & 11 & 42 \\
\hline Eastern ice shelf $(7,8)$ & & & & 6 & 26 \\
\hline Western tributaries $(1-5)$ & & & & 16 & 63 \\
\hline Eastern tributaries (6-8) & & & & 9 & 37 \\
\hline
\end{tabular}

Note: Velocity data are estimated from Figure 1 in Budd et al. (1982): ice thickness is taken to be constant at 360 $\mathrm{m}$, the mean value estimated on the eastern half of the transverse profile from Figure 6 in Budd et al. (1982). Note that about $40 \%$ of the ice thickness is derived as a result of freeze-on of basal ice.

a Summary data for various parts of the ice shelf.

if any of the tributaries of Lambert Glacier surged, debris might be transported across to the other side of the valley and thereafter transported downstream on the side opposite to that which would be the case if steady state conditions prevailed. It is therefore important to consider what is the evidence for surging.

\section{Does the Lambert Glacier-Amery Ice Shelf System Surge?}

It has been suggested that one of the major tributaries of the Lambert Glacier-Amery Ice Shelf system, the Fisher Glacier, is of the surge type (Wellman, 1982). On the basis of moraines recognized in aerial photographs, $150-200 \mathrm{~m}$ above the present ice level in the lower Fisher Glacier, he suggested that this glacier has undergone repeated surging in the past. However, Wellman does not specify the age of the moraines nor the surge frequency.

Supposed additional evidence of surging comes from the results of modeling the East Antarctic ice sheet and considerations of the flux rate and surface slope of Lambert Glacier, which suggest that present flow out of the basin is incompatible with steady state flow (Budd and Mclnnes, 1978; Allison, 1979). Also, the glaciological data used indicate that discharge from the basin is only one-half the average annual accumulation rate supplying mass to the basin (Allison, 1979). This build-up of ice has thus been taken to indicate that the system may be in the post-surge build-up phase. More recently, McIntyre (1985a) has found that Landsat imagery indicates the Lambert drainage basin to be $17 \%$ smaller than previous estimates and that surface ablation may be of greater significance than previously believed, with $56 \mathrm{~km}^{2}$ of bare ice exposed. The effect of this is to more-orless equalize accumulation and discharge and, thus, to suggest no evidence of surge behavior.

The structural evidence presented here does not support the surge hypothesis of any part of the Lambert Glacier-Amery Ice Shelf system. None of the structural features characteristic of surge-type glaciers, notably teardrop-shaped, looped moraines and contorted foliation, which results from pulsating flow of tributaries, is present. Therefore, if surging occurred it would have been spread evenly across the whole basin simultaneously, a most unlikely event. Alternatively, the surging period could exceed the residence time of ice in the system. As the residence time for ice in marginal areas is likely to exceed many thousands of years, and several hundreds of years for ice in midstream, I consider that surging has not been a feature of this system in the last $10,000 \mathrm{yr}$ or more. Nothing can be said in this regard about earlier times, and indeed, Budd and McInnes' (1978) surge frequency was much greater than this figure $(23,000 \mathrm{yr})$. Nevertheless, steady state flow is assumed in the following discussion.

\section{Sources of Debris for the Prydz Bay Drill Sites}

At present, little debris is transported at the surface of the Lambert Glacier-Amery Ice Shelf system. At the current level of glacierization it is unlikely that any more debris was transported in the past, as outcrops are of limited extent. When ice cover was sufficiently great to allow grounded ice to reach the edge of the continental shelf, outcrops of rock would have been even more limited in extent. Thus, most of the debris reaching Prydz Bay will have been transported subglacially, a view supported by the roundness character of clasts at Sites 739 and 742 (Hambrey et al., this volume).

Depositional processes today are fundamentally influenced by the thermal character of the ice shelf. Although considerable basal melting occurs at the grounding line, a layer of ice of oceanic origin begins to freeze onto the base a short distance downstream. This oceanic ice reaches a thickness of $200 \mathrm{~m}$. Even at the calving limit, the frozen-on ice represents around $40 \%$ of the total thickness of the ice shelf. Thus, englacial debris that is not melted out at the grounding line will not be released until icebergs become detached from the ice shelf and disintegrate.

In view of the contemporary drift paths of bergs west along the Antarctic coast, much of the debris from the Lambert Glacier system is probably deposited up to hundreds of kilometers west of Prydz Bay. By the same token, present-day terrigenous sediment currently being deposited in Prydz Bay by icebergs may have originated much further to the east, for example in the numerous glacier tongues that extend out from the coast of East Antarctica.

The recognition of individual flow units (Fig. 7) has allowed us to provisionally define the most likely sources of material for those periods when ice was grounded to the continental shelf break. The heterogeneous nature of the metamorphic and igneous basement, which dominates the exposed areas makes matching clasts with source areas on lithological grounds difficult. 
However, distinctive rock types such as fuchsite-bearing quartzite (only a few clasts recorded in the ODP cores) and the banded iron-formations (one clast recovered) of the southwestern Prince Charles Mountains, are poorly represented. This supports the hypothesis, outlined previously on the basis of flow lines, that not much ice reached the Prydz Bay drill sites from the western side of the Lambert Glacier-Amery Ice Shelf system.

A major component of the Prydz Bay cores that is not recorded in outcrop is from the geophysical-determined sedimentfill in the Lambert Graben. Sedimentary clasts, and more particularly the matrix, in the Prydz Bay diamictites of Sites 742, 739 , and 743 originate from a sedimentary sequence that must have been far more extensive than the present-day small area of Permian rocks at Beaver Lake. The overdeepened part of the Lambert Glacier trough, now filled with ice (Fig. 4), was the main source of this sediment, with additional sediment originating from the graben on the eastern side of the Mawson Escarpment.

The initiation of glaciation, and the source of debris when ice first reached the sea, remain open questions. Alpine glaciation would have begun first on the Gamburtsev Subglacial Mountains, the Prince Charles Mountains, and the Grove Mountains. However, ice is unlikely to have extended as far as present-day Prydz Bay until the alpine glaciers had coalesced to form a near-continuous ice sheet. In terms of glacial erosion, and thus sediment transport, there must have been a time when the Lambert Graben glaciers, the Fisher, Mellor, and Lambert, were the most efficacious parts of the system. However, in terms of ice entering Prydz Bay today, their influence is less than that of ice generated in the region nearer the coast.

\section{ACKNOWLEDGMENTS}

This paper was written while the author was a Guest Scientist at the Alfred Wegener Institute for Polar and Marine Research. Professor D. K. Fütterer is thanked for arranging the provision of resources. NATO Research Grant $0232 / 89$ has also facilitated this research. Holly Fergusen (U.S. Geological Survey, Flagstaff) is thanked for locating the relevant Landsat images, and Imke Engelbrecht (AWI) and David Bull (Scott Polar Research Institute) for drafting most of the figures. Thanks also are due to Dr. W. U. Ehrmann for reviewing the manuscript, and to Dr. G. de Q. Robin for advice concerning the glaciology of the region.

This is contribution no. AWI 320 of the Alfred Wegener Institute for Polar and Marine Research.

\section{REFERENCES}

Allison, 1. F., 1979. The mass budget of the Lambert Glacier drainage basin, Antarctica. J. Glaciol., 22:223-235.

Allison, I. F., Young, N. W., and Medhurst, T., 1985. On re-assessment of the Lambert Glacier drainage basin, Antarctica (letter). J. Glaciol., 31:378-381.

Budd, W., 1966. The dynamics of the Amery Ice Shelf. J. Glaciol., 6: 335-358.

Budd, W., Corry, M. J., and Jacka, T. H., 1982. Results from the Amery Ice Shelf Project. Ann. Glaciol., 3:36-41.

Budd, W., and McInnes, B. J., 1978. Modelling surging glaciers and periodic surging of the Antarctic ice sheet. In Pittock, A. B., Frakes, L. A., Jenssen, D., Peterson, J. A., and Zillman, J. W. (Eds.), Climatic Change and Variability: A Southern Perspective: Cambridge (Cambridge Univ. Press), 228-233.

Derbyshire, E., and Peterson, J. A., 1978. A photo-geomorphic map of the Mt. Menzies nunatak, Prince Charles Mountains, Australian Antarctic Territory. Z. Gletscherk. Glazialgeol., 14:17-26.
Drewry, D. J. (Ed.), 1983. Antarctica: Glaciological and Geophysical Folio: Cambridge (Scott Polar Research Institute).

Fedorov, L. V., Grikurov, G. E., Kurinin, R. G., and Masolov, V. N., 1982. Crustal structure of the Lambert Glacier area from geophysical data. In Craddock, C., Loveless, J. K., Vierima, T. L., and Crawford, K. (Eds.), Antarctic Geoscience: Madison (Univ. Wisconsin Press), 931-936.

Hambrey, M. J., 1975. The origin of foliation in glaciers: evidence from some Norwegian examples. J. Glaciol., 14:181-185.

1977. Foliation, minor folds and strain in glacier ice. Tectonophysics, 39:397-416.

Hambrey, M. J., and Mller, F., 1978. Ice deformation and structures in the White Glacier, Axel Heiberg Island, Northwest Territories, Canada. J. Glaciol., 20:41-66.

Hollin, J., 1969. Ice sheet surges and the geological record. Can. J. Earth Sci., 6:913-918.

Hooke, R. L., and Hudleston, P. J., 1978. Origin of foliation in glaciers. J. Glaciol., 20:85-299.

McIntyre, N. F., 1985a. A re-assessment of the mass balance of the Lambert Glacier drainage basin, Antarctica. J. Glaciol., 31:34-38. , 1985b. On re-assessment of the Lambert Glacier drainage basin, Antarctica (reply). J. Glaciol., 31:382.

Mond, A., 1972. Permian sediments of the Beaver Lake area, Prince Charles Mountains. In Ladie, R. J. (Ed.), Antarctic Geology and Geophysics: Oslo (Universitetfolaget), 585-589.

Morgan, V. I., and Budd, W. F., 1975. Radio-echo sounding of the Lambert Glacier basin. J. Glaciol., 15:103-111.

Oliver, R. L., James, P. R., Collerson, K. D., and Ryan, A. B., 1982. Precambrian geologic relationships in the Vestfold Hills, Antarctica. In Craddock, C. (Ed.), Antarctic Geoscience: Madison (Univ. Wisconsin Press), 435-444.

Quilty, P. G., 1985. Distribution of foraminiferids in sediments of Prydz Bay, Antarctica. Spec. Publ. S. Aust. Dep. Mines Energy, 5:329340.

Ravich, M. G., and Federov, L. V., 1982. Geological structure of MacRobertson Land and Princess Elizabeth Land, East Antarctica. In Craddock, C. (Ed.), Antarctic Geoscience: Madison (Univ. Wisconsin Press), 499-504.

Ravich, M. G., Solov'ev, D. S., and Federov, L. V., 1984. Geological Structure of MacRobertson Land (East Antarctica): Washington (Nat. Sci. Found.) and New Delhi (Amerind Publishing). (Translated from 1978 Russian text)

Reynolds, J. M., 1988. The structure of Wordie Ice Shelf, Antarctic Peninsula. Br. Antarct. Surv. Bull., 80:57-64.

Reynolds, J. M., and Hambrey, M. J., 1988. The structural glaciology of George VI Ice Shelf, Antarctica. Br. Antarct. Surv. Bull., 79:7995.

Robin, G. de Q., 1979. Formation, flow and disintegration of ice shelves. Glaciology, 24:259-271.

1983. Coastal sites, Antarctica. In Robin, G. de Q. (Ed.), Climatic Record in Polar Ice Sheets: Cambridge (Cambridge Univ. Press), 118-122.

Stagg, H.M.J., 1985. The structure and origin of Prydz Bay and MacRobertson Shelf, East Antarctica. Tectonophysics, 114:315-340.

Swithinbank, C.W.M., 1969. Giant icebergs in the Weddell Sea, 196768. Polar Rec., 14:477-478.

1988. Satellite Image Atlas of the World: Antarctica. Geol. Surv. Prof. Pap. U.S., 1386-B.

Tingey, R. J., 1982. The geologic evolution of the Prince Charles Mountains-an Antarctic cratonic block. In Craddock, C. (Ed.), Antarctic Geoscience: Madison (Univ. Wisconsin Press), 455-464.

Wellman, P., 1982. Surging of Fisher Glacier, Eastern Antarctica: evidence from geomorphology. J. Glaciol., 28:23-28.

Date of initial receipt: 16 December 1989

Date of acceptance: 18 June 1990

Ms 119B-201 


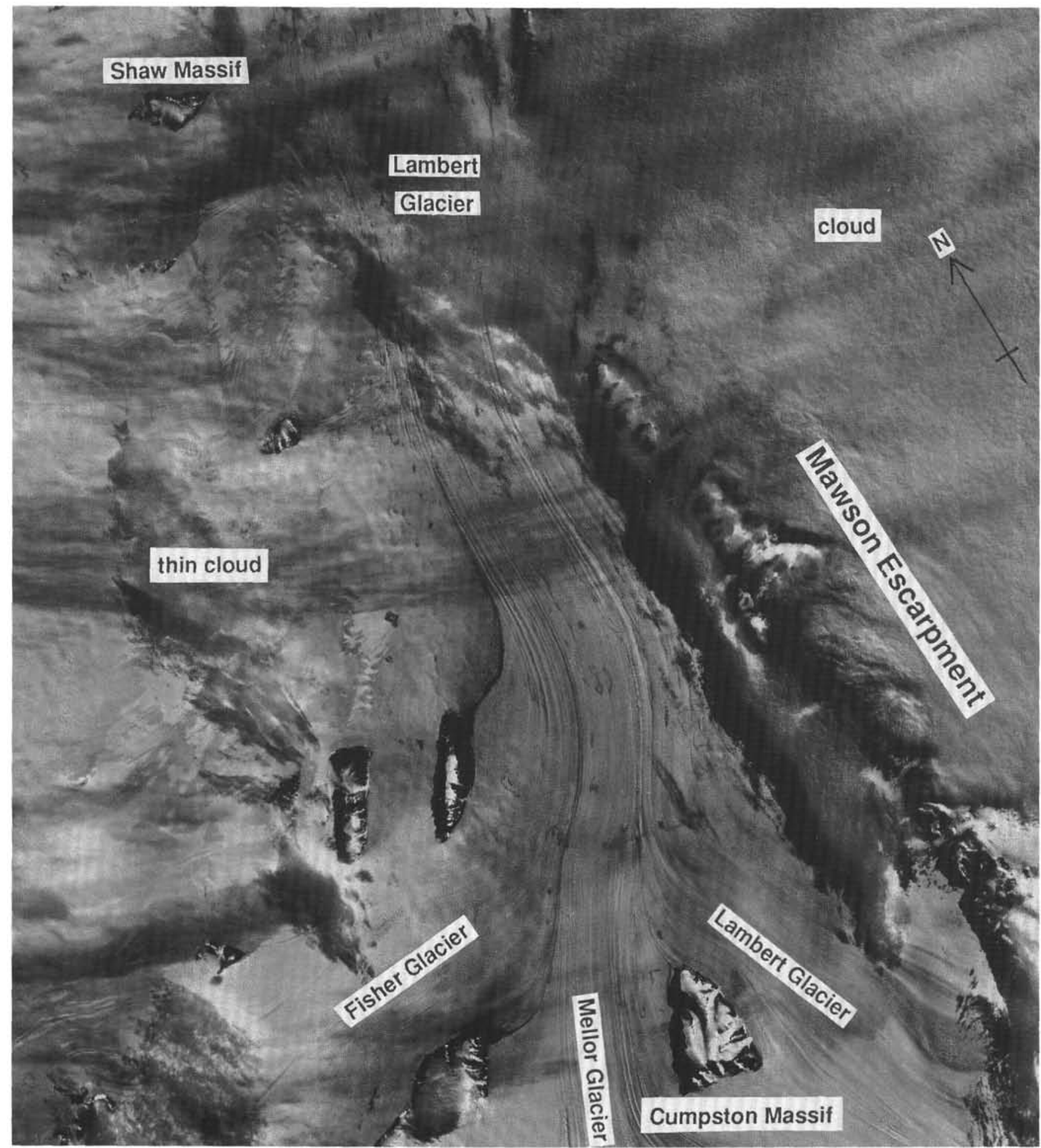

Plate 1. Landsat image no. 1577-03045 of the confluence region of the Lambert, Mellor, and Fisher glaciers, dated 20 February 1974. Linear structure is the dominant longitudinal foliation, parallel to which are moraines and meltstreams in the main trunk glacier. Supraglacial lakes are also present. Areas of heavy crevassing can be faintly seen in the three tributary glaciers. Width of image about $170 \mathrm{~km}$, height of image about $190 \mathrm{~km}$. Image published by permission of U.S. Geological Survey, Image Processing, Flagstaff, AZ. 